\title{
A multidisciplinary study of a syntectonic pluton close to a major lithospheric-scale fault-Relationships between the Montmarault granitic massif and the Sillon Houiller Fault in the Variscan French Massif Central: 2. Gravity, aeromagnetic investigations, and 3-D geologic modeling
}

\author{
Aurore Joly : Institut des Sciences de la Terre d'Orléans, CNRS/INSU, Université d'Orléans \\ UMR 6113, Orléans, France et Bureau de Recherches Géologiques et Minières, Orléans, \\ France
}

Guillaume Martelet : Bureau de Recherches Géologiques et Minières, Orléans, France

Yan Chen and Michel Faure :

Institut des Sciences de la Terre d'Orléans, CNRS/INSU, Université d'Orléans UMR 6113, Orléans, France Abstract

\begin{abstract}
New gravity and aeromagnetic investigations have been carried out to understand the emplacement mechanisms of a granitic pluton and the relationships with a nearby lithospheric-scale fault. This paper concerns the second part of a methodological multidisciplinary study and complements previous geochronologic and Anisotropy of Magnetic Susceptibility (AMS) studies on the same pluton. In the northern part of the Variscan French Massif Central (FMC) the Montmarault massif crops out along the Sillon Houiller Fault (SHF). Bouguer and aeromagnetic anomaly maps imply thickening of the pluton along the SHF and suggest laccolitic spreading northwestward. On the basis of petrophysical measurements, direct two-dimensional (2-D) joint gravity and magnetic modeling has been performed along 10 cross sections. In order to quantitatively constrain the 3-D pluton geometry and its relationships with surrounding geologic units, these geophysical cross sections, new structural information (field and AMS measurements), and petrophysical data have been integrated into a regional 3-D geological and geophysical model. Altogether, the results obtained from geochronology, petromagnetic fabrics (part 1), gravity, and aeromagnetic investigations as well as 3-D modeling (part 2) demonstrate that the Montmarault pluton was emplaced during the Namurian period along the SHF. Our results further show that at that time, in response to a NW-SE regional extension, if the SHF existed, it behaved as a normal fault. Mylonites attesting for synmagmatic normal motion on the northeastern part of the Montmarault pluton strengthen this tectonic scenario. During the Late Carboniferous the FMC experienced NE-SW extension along the SHF by $80 \mathrm{~km}$ of brittle left lateral wrench offset. This second tectonic event is well recorded in the Stephanian coal basins which were formed along NW-SE listric brittle faults and constrain the present-day shape of the Montmarault pluton.
\end{abstract}

Keywords: granitic pluton, gravity and magnetic investigations, 3-D modeling, European Variscan Belt, French Massif Central. 


\section{Introduction}

Studies of large scale crustal to lithospheric deformations documented worldwide show that various amounts of localized [Tapponier and Molnar, 1979; Ledru et al., 1989] versus distributed and continuous [Molnar, 1988; Teyssier and Tikoff, 1998; Vanderhaege and Teyssier, 2001; Schellart and Lister, 2005] deformation can occur. When the large crustal or lithospheric tectonic structures accommodate the main part of the deformation, such as in the French Massif Central, they represent key geological objects for the understanding of regional tectonic history. Tectonic structures preserve information on the deformation mechanisms recorded during the orogenic phase. They may document the dynamic evolution of geologic terrains. However, the primary events are often erased by younger ones since multiphase deformations generally reactivate these ancient structures.

Over the past decade, there has been extensive work documenting the emplacement of plutons in a variety of structural settings. Pluton emplacements were described in extensional tectonic environments such as pull-apart structures [e.g., McCaffrey, 1992; Tikoff and Teyssier, 1992; Crawford et al., 1999], tensional cracks [ㅂutton, 1982; Castro, 1986; McNulty et al., 2000], shear zone terminations [Hutton, 1988; $\underline{\text { Neves and Vauchez, 1995; Tikoff and de Saint }}$ Blanquat, 1997], flower structures [Pe-Piper et al., 1998], and on the shoulders of shear zones [Weinberg et al., 2004]. In recent years, application of gravity, magnetic and Anisotropy of Magnetic Susceptibility (AMS) techniques has contributed to important advances in the understanding of pluton emplacement mechanisms, and in the use of syntectonic granitoids as markers of regional kinematics and strain fields [Cruden and Launeau, 1994; Leblanc et al., 1994, 1996; Bouchez and Gleizes, 1995; Tobisch and Cruden, 1995; Benn et al., 1997, 1998; Gleizes et al., 1997].

In the French Massif Central (FMC), the 500-km-long Sillon Houiller Fault (SHF) is a major tectonic structure: its Late Carboniferous (circa 320-300 Ma) activity at the end of the Variscan orogeny has already been demonstrated [Grolier and Letourneur, 1968; Feybesse, 1981; Belin, 1983]. However, its exact tectonic style and timing remain largely uncertain, except the $80 \mathrm{~km}$ of brittle left lateral wrench movement, associated with the development of Stephanian (circa $300 \mathrm{Ma}$ ) coal basins [e.g., Grolier and Letourneur, 1968; Bonijoly and Castaing, 1984]. In the field, direct evidence for ductile shearing is quite rare [Feybesse, 1981]; thus, in order to document the early SHF activity, we have studied the relationships between the SHF and a nearby granitic massif.

The Montmarault granitic massif (Figure 1a) is located at the northern end of the SHF (Figure 1b) and is geologically juxtaposed to the west of it. In the companion paper [Joly et al., 2007] (hereinafter referred to as part 1), this pluton has been dated by the U-Th-Pb method at $321 \pm$ $2 \mathrm{Ma}$ and the internal fabrics revealed by Anisotropy of the Magnetic Susceptibility (AMS) study show a dominant NW-SE lineation trend that complies with the regional late orogenic extensional tectonic field developed during the Namurian time [Faure, 1995].

In this article, we present results from potential field modeling, which allow assessment of the pluton geometry at depth. We thereby complement results presented in part 1 of this study based essentially on the observations at the surface. Joint AMS and gravity studies have been already carried out to infer the 3-D geometry (from gravity) and the regional deformation during emplacement (from AMS) of several plutons [e.g., Vigneresse and Brun, 1983; Améglio et al., 1997; Talbot et al., 2005; Gébelin et al., 2006]. Here, we complement this approach by joint gravity and magnetic modeling, which strengthens the modeled geology. In 
order to constrain this modeling, petrophysical parameters (density and magnetic susceptibility) were determined by laboratory or field measurements, for each encountered lithology. Furthermore, modeling of several cross sections strengthens the geometrical and topological consistency of the interpretative geological model. Finally, an ad hoc 3-D geostatistical interpolation [Lajaunie et al., 1997; Guillen et al., 2000] of these cross sections, surface geological data as well as AMS foliations provides a full 3-D geometrical model (of $59 \times 62 \times 8 \mathrm{~km}^{3}$ extent), centered on the Montmarault pluton. Though nonunique, the obtained model is consistent with available geophysical data and integrates the present-day geological knowledge.

This study (1) provides a methodology for integrating multidisciplinary information into a realistic geological 3-D model and (2) allows us to infer the shape of the pluton at depth and to characterize its relationships with the SHF. In light of results obtained in both part 1 and part 2 of this study, an emplacement model of the pluton is proposed, and its implications on the understanding of the Variscan ductile tectonics along the SHF are discussed.

\section{Geological Setting}

\subsection{Variscan Orogeny of Western Europe}

In western Europe, the Variscan belt resulted from the collision between Gondwana and Laurussia in the Late Devonian to Early Carboniferous times [Matte, 1986]. Oceanic and subsequent continental subduction occurred during the Late Silurian-Devonian [e.g., Santallier et al., 1994; Lardeaux et al., 2001].

Continent-continent collision and associated crustal thickening occurred during the Devonian to Carboniferous and caused thrust and wrench tectonics [Brun and Burg, 1982]. Then, from 330 to $300 \mathrm{Ma}$, the belt experienced late orogenic extensional tectonics [Van den Driessche and Brun, 1989; Faure et al., 2005]. Crustal thinning described in several places in the FMC consists of two successive and distinct extensional events [Ménard and Molnard, 1988; Van den Driessche and Brun, 1989; Faure and Becq-Gireaudon, 1993; Burg et al., 1994; Faure, 1995].

The first one, in Namurian-Westphalian time (about 330-315 Ma), is characterized by an orogen-parallel NW-SE maximum stretching direction [Faure, 1995]. This NW-SE extensional tectonics is diachronous throughout the FMC since in the north, the late-orogenic extension event started in Late Visean (circa $330 \mathrm{Ma}$ ), while in the south (i.e., Montagne Noire and Cévennes areas), the compression was still active at that time. In the southern FMC, the onset of this NW-SE late-orogenic extensional event occurred in Westphalian (circa 320-315 Ma).

The second extensional phase of Stephanian-Autunian time (circa 310-290 Ma) is a postorogenic event and characterized by a NE-SW maximum stretching direction (i.e., subperpendicular to the general trend of the belt) and by the emplacement of rare granitic plutons and the Velay migmatitic dome. The role of granitic plutons as markers of the late stage of orogenic evolution of the Variscan belt is now well documented by geochronological, petrological and geophysical studies on several Namurian synkinematic granitic massifs (Figure 1b), such as la Margeride [Talbot et al., 2005], Millevaches [Gébelin et al., 2004, 2006], Rocles [Be Mezème et al., 2006] or Mont Lozère-Borne [Talbot et al., 2004]. In the FMC, the NE-SW extensional regime is well recorded by brittle deformation associated with 
the opening of several Stephanian coal basins [Blès et al., 1989]. Along the SHF, the Stephanian coal basins are coeval with $\sim 80 \mathrm{~km}$ of left-lateral wrenching [Grolier and Letourneur, 1968].

Ductile tectonics along the SHF, however, is poorly documented [Feybesse, 1981] and an attempt to interpret it as a transfer fault accommodating different rates of the late orogenic extension was proposed [Burg et al., 1990]. However, this assumption is not in accordance with the existence of the two distinct and successive episodes of extensional tectonics [Faure, 1995] that we have reviewed earlier in this section. Consequently, in order to bring indirect constraints on the ductile tectonic style of the SHF, in relation with a plutonic event, we investigate the Montmarault granitic pluton which crops out along the SHF.

\subsection{Geological Framework in the Northeast of the FMC}

The Montmarault massif was emplaced in metamorphic series of biotite-sillimanite migmatites, biotite-sillimanite gneisses and biotite-muscovite micaschists (Figure 1a). These series compose the para-authochtonous country rocks which were overlain by thrust sheets. The Barrovian metamorphism affecting the para-authochtonous unit is coeval with the napping tectonics which took place during the Silurian-Carboniferous time [Matte, 1986; Ledru et al., 1989; Faure et al., 2005; and references therein]. The metamorphic series were then intruded by the Carboniferous Guéret pluton (Figure 1b) [Berthier et al., 1979; Cartannaz et al., 2006]. The Montmarault granitic massif dated at $321 \pm 2 \mathrm{Ma}$ (see part 1) was emplaced during the late-orogenic extensional phase of the Variscan orogen [Ménard and Molnard, 1988; Van Den Driessche and Brun, 1989; Faure and Becq-Gireaudon, 1993; Burg et al., 1994; Faure, 1995]. Monazites dated in Montmarault granite are unzoned and have not recorded any deformation according to their magmatic texture (see part 1). Consequently, the age of $321 \pm 2 \mathrm{Ma}$ is coeval with pluton emplacement. The massif (Figure 1a) consists mainly of porphyritic granite, known as the Montmarault granite sensu stricto, which is locally intruded by leucogranite stocks and dikes. Separated by a transition zone, two types of granitic facies have been defined within the massif (Figure 1a) [Boissonas and Debeglia, 1976; Sossa-Simawango, 1980]. From a mineralogical point of view, the western part presents a predominance of weakly hydrated or oxidized minerals while the eastern one is rich in orthoclase and quartz and poor in plagioclase and ferromagnesian phases. Petrological studies reveal deep magma origin and its rapid emplacement close to the surface [Sossa-Simawango, 1980]. Compared to other plutons already studied in the French Massif Central, the depth of emplacement of the Montmarault pluton is rather shallow at about $2 \mathrm{~km}$. This conclusion is enforced by a high concentration of magnetite and the abundance of orthoclase instead of microcline [Sossa-Simawango, 1980], suggesting fast crystallization at high temperature and low depth [Boissonas and Debeglia, 1976]. Rock fabrics studied in detail in companion paper part 1 highlight the predominance of magmatic microstructures and weak solid-state deformation, indicating that the Montmarault pluton acquired its magmatic fabrics during its emplacement. The only part of the massif where the intense solid-state microstructures are significantly developed is observed by Barbarin et al. [1985] in the northwestern part of the eastern branch of the massif. The granitic rocks present intense planar and linear fabrics corresponding to the mylonitic margin of the pluton with a top-to-the-NW ductile shearing, associated to a foliation pattern gently dipping to the NW and to a vertical lineation. This structural observation indicates normal faulting.

Eventually, several Stephanian half-graben coal basins formed, bounded by NE dipping normal faults, which currently overlie the pluton (e.g., Commentry and Doyet; 


\section{Geophysical Data}

Despite the lack of geophysical studies specifically devoted to the SHF fault, several studies imply its crustal or even lithospheric extent. Seismic tomography [Granet et al., 1995a, 1995b] as well as seismic anisotropy [Babuška et al., 2002; Granet et al., 2000], suggest that the SHF separates two distinct lithospheric domains, down to about $200 \mathrm{~km}$ in depth. At the crustal scale, a crustal thickness difference across the SHF has been evidenced by seismic refraction [Perrier and Ruegg, 1973; Zeyen et al., 1997], heat flux modeling [Lucazeau et al., 1984] and thermal modeling constrained by seismic, gravity and petrologic data [Sobolev et al., 1997].

These results emphasize the recent lithospheric dynamics under the FMC but the Variscan activity of the SHF is not documented. At the crustal scale, geophysical data, such as seismic reflection that would allow us to decipher the upper crustal structures along the SHF, are not available. However, it is obvious that the structure of the crust, or even the lithosphere, of the early SHF, around $300 \mathrm{Ma}$, may have influenced the deformation experienced along the SHF since then. The Montmarault pluton, which was emplaced along the SHF during its probable ductile activity, might provide indirect constraints to assess the tectonic style at that time. In this paper, regional modeling has been performed by combining gravity and magnetic investigations in order to image the 3-D geometry of the pluton in relation with the SHF and to characterize the regional deformation during its Namurian emplacement.

\subsection{Gravity Data}

A Bouguer anomaly map of the Montmarault massif including the existing data coming from the "Banque Gravimétrique de la France" and 525 new stations was prepared. Gravity measurements were carried out throughout the entire pluton in the gap area with the existing gravity data, using a SCINTREX CG3-M micro-gravimeter. This led to an average coverage of one station per square kilometer. The whole data set was tied to the CGF65 French gravity reference network. The gravity anomaly was computed with respect to the theoretical value of $\mathrm{g}$ on Hayford-1930 ellipsoid. In order to obtain the complete Bouguer anomaly, we successively performed standard free air, plateau and terrain corrections. Terrain corrections were computed to a distance of $167 \mathrm{~km}$, following the procedure detailed by Martelet et al. [2002]. In order to be close to the expected density of the granites, a Bouguer reduction density of $2.6 \mathrm{~g} . \mathrm{cm}^{-3}$ was used. As we focus on plutons cropping out at the surface, the long wavelengths in the Bouguer anomaly were removed by fitting a polynomial of degree 3 to the Bouguer anomaly for the entire Massif Central. The gravity data were finally interpolated using a standard minimum curvature algorithm, resulting in a 500-m anomaly grid.

To the first order, the residual Bouguer anomaly of the Montmarault area, reflecting the heterogeneous distribution of masses at depth, is consistent with geological boundaries (Figure 2a). Positive anomalies, corresponding to mass excess, that is to say, to high densities, are normally associated with the basement, whereas sedimentary basins or/and granite, which have lower densities (Table 1), are prominently displayed as negative anomalies. The SHF is well defined on the Bouguer anomaly map: it is outlined by a sharp gravity gradient corresponding to the contact between the low-density Montmarault pluton to the west and the high-density Sioule metamorphic series to the east. The negative anomaly along the SHF suggests thickening of the pluton in relation with the fault. In contrast, the northwestern branch of Montmarault massif is unexpectedly associated with a positive gravity anomaly. This suggests that the northwestern extension of the Montmarault pluton is thin and that the 
underlying basement is close to the surface, since no density variation exists inside the pluton (Table 1). Therefore the massif spreads northwestward from the Sillon Houiller fault, as a laccolith. North of the Montmarault massif, the Aumance Permian-Stephanian basin is characterized by a negative anomaly suggesting that the sedimentary rocks become thicker to the SE, up to the fault (next Murat), that forms the contact with the Montmarault pluton. In the centre of the Montmarault massif, the Commentry and Montvicq half-grabens are also underlined by negative anomalies.

\subsection{Airborne Magnetic Data}

Figure $2 \mathrm{~b}$ shows the magnetic anomaly map, reduced to the pole over the Montmarault area. Original data come from a regional airborne survey carried out in 1972, with 2-km line spacing and $1200-\mathrm{m}$ barometric flight height. The data were interpolated on a $500-\mathrm{m}$ grid [Edel and Gachon, 1973; Debeglia, 1973]. In order to relocate anomalies above causative geological bodies, anomalies were reduced to the pole with an inclination of $62^{\circ}$ and a declination of $5^{\circ} \mathrm{W}$, which corresponds to the average orientation of the magnetic field at the time and in the zone of the survey. Extensive qualitative interpretations of these data have been previously published [Debeglia and Gérard, 1975; Boissonas and Debeglia, 1976]. Here, we briefly comment on the main magnetic anomalies in relation with the Montmarault massif and its surrounding structures. We further quantitatively analyze the anomalies through 2-D modeling.

As previously interpreted, in the Montmarault area, the SHF separates two distinct magnetic domains: to the west, the Montmarault granitic massif exhibits high-amplitude anomalies, whereas to the east, metamorphic units are mainly nonmagnetic. To the first order, the Vshaped magnetic anomaly correlates well with the outcropping limits of the pluton. Parallel to the outcropping limits of the Montmarault pluton, the reduced to the pole magnetic anomaly map (Figure 2b) shows an alternation of positive and negative anomalies: when compared to the geological map, the positive anomalies correspond to the granitic massif, whereas the negative ones are related to the metamorphic basement or the Permo-Stephanian sedimentary basins. To the southwest of the massif, low magnetic amplitudes are mostly related to migmatitic units, whereas, to the north, they correspond to the Aumance basin. Low anomalies are also associated with the Commentry and Montvicq Stephanian half-grabens, which are intercalated in between two branches of Montmarault batholith. Along the SHF as well, several small negative anomalies correspond to Stephanian basins, such as the St-Eloy coal basin. Indeed, metamorphic units and sedimentary basins have low magnetic susceptibilities ranging from 25 to $630 \mu$ SI (Table 1). In contrast, the only lithologies that have significant magnetic susceptibilities are the Montmarault granitic pluton itself (ranging from 10 to $13200 \mu \mathrm{SI}$ ) within distinct facies (Figure 1a) and diorites (around $15000 \mu \mathrm{SI}$ ). In this area, several dioritic intrusions occur either within or in close contact with the Montmarault pluton, and are outlined by a strong magnetic anomaly, such as near Cosne d'Allier/Hérisson, north of the study area, or near Villefranche, to the west of the SHF.

This observation led us to hypothesize that the magnetic anomalies apparently induced by the Montmarault pluton might be partly due to underlying dioritic intrusions. This is suggested, in particular, by the association of both positive magnetic and gravity anomalies under the western branch of Montmarault massif. Indeed, in this area, the entire magnetic anomaly cannot derive from the pluton only (even if its susceptibility is high), since its thickness is small, evidenced by the positive gravity anomaly. The occurrence of dioritic intrusives, 
underlying the granitic rocks, is therefore introduced in the modeling and will be further discussed in following sections.

\subsection{AMS Data}

The internal structure of the Montmarault pluton has been studied by AMS and petrostructural methods (part 1 of this study) and only necessary information for the modeling are recalled here. A NW-SE mineral and magnetic lineation is nearly perpendicular to the SHF in a conspicuous feature. In the eastern part of the massif along the SHF, the magnetic foliation pattern generally presents a high dip to the southeast (Figure 13 and Table 1 in part 1). In the northwestern branch of the massif, the magnetic foliation is gently dipping about $30^{\circ}$ to the southwest. To the south of Commentry in the southwestern part of the massif, the magnetic foliation strikes in the NW-SE direction and dips $40^{\circ}$ to the northeast.

\section{Two-Dimensional Forward Gravity and Magnetic Modeling}

On the basis of the geological knowledge, two-dimensional (2-D) forward gravity and magnetic modeling has been performed using the Geosoft-GM-SYS software along ten cross sections distributed all over the Montmarault pluton (see location on Figure 2). Twodimensional and three-dimensional magnetic modelings are based on the reduced to pole map. In order to avoid edge effects, 2-D cross sections were extended for one third of their length at each extremity of the profile. Five profiles are drawn perpendicularly to the SHF to image the relationships between the Montmarault massif and the SHF, while other five profiles crosscut the western branch of the Montmarault pluton and the associated half-graben coal basins. Modeling of several cross sections improves the geometrical and topological consistency of the interpretative geological model. Furthermore, the joint gravity and magnetic modeling constrains the geometry of a geological source both in terms of density and magnetic contrast with surrounding rocks. Therefore, taking into account measured petrophysical properties, the joint gravity and magnetic modeling tightly constrains the geological interpretation [Menichetti and Guillen, 1983]. Though nonunique, the obtained model is compatible with both available potential field data and integrates the present-day geological knowledge.

[24] Average densities of the modeled geological units (Figure 3) were derived from rock density measurements. The densities of 35 samples were determined (Table 1) using the double weighting method, further complemented by several liquor density determinations to calibrate accurately the density measurements. Magnetic susceptibilities of rocks were measured in the field using a SatisGeo KT-6 portable kappameter. In each of the 63 measured sites, the susceptibility was averaged from a series of punctual determinations. The Montmarault pluton, however, is characterized by a large range of magnetic susceptibilities: the values used for the modeling range from $13200 \mu \mathrm{SI}$ in the western branch of the massif, which is higher than most comparable plutons in the French Massif central, to $6300 \mu \mathrm{SI}$ in its south-central part and $10 \mu \mathrm{SI}$ in the facies close to the SHF. This heterogeneity is due to the presence or absence of magnetite. Chemical variations within the pluton and/or oxygen fugacity variations are likely to be the cause of the crystallization of the magnetite in the Montmarault pluton (see part 1 for details).

These ranges of rock densities and magnetic susceptibilities are in good agreement with previous measurements of the same study area [Debeglia and Gérard, 1975; Boissonas and Debeglia, 1976; Sossa-Simawango, 1980], and are also in accordance with those obtained 
from comparable geological contexts in the French Massif central [e.g., Talbot et al., 2004; Gébelin et al., 2006].

In addition to the petrophysical determinations, other constraints used for the geophysical modeling primarily concern the knowledge of geological units, contacts and structural data. When one performs direct modeling of the geophysical anomalies, this combination of constraints drastically decreases the degrees of freedom of geologic models; and this is even amplified when gravity and magnetic anomalies are integrated together into a model. Furthermore, the integration of the available information as well as the condition of coherent crossings among all the 10 modeled cross sections requires very careful matching of the geological model to the geophysical constraints. Density and magnetic susceptibilities being fixed, every small variation of thickness of the modeled geological bodies can significantly modify the gravity and/or magnetic contribution of the model. These considerations are particularly true close to the surface where we estimate the position of interfaces to be accurate within 100 to $500 \mathrm{~m}$, depending on the petrophysical contrast on interfaces considered. As discussed in the following, for deeper interfaces where constraints are more scarce, and petrophysical contrasts sometimes low, the accuracy of the model slightly decreases (to within $1 \mathrm{~km}$ ), and should be considered as regionally significant.

According to regional tectonic and metamorphic studies [Ledru et al., 1989; Faure et al., 2005], the Montmarault host rocks consist of gneiss and micaschist series overthrust by higher grade terrains. This stack of nappes is well exposed to the east of the SHF around the Sioule metamorphic series [Faure et al., 1993], but crops out only locally in the vicinity of the Montmarault massif (Figure 1a). In our modeling, interfaces between these metamorphic units were primarily modeled according to the geological map and keeping these interfaces as smooth as possible at depth. In particular, due to the weak magnetic and density contrast between micaschists and gneisses, the interface between these metamorphic units is poorly constrained. It is, however, regionally coherent, for instance, with the same interface modeled in the Millevaches area [Gébelin et al., 2004], about $100 \mathrm{~km}$ southwest of Montmarault. The interface between the gneiss and overlying migmatites is also partly constrained by the surface geology; at depth, the density contrast and to a lesser extent the magnetic susceptibility contrast provide acceptable constraints to model the interface between both units.

In Figure 3, we present two representative cross sections out of ten modeled, which exhibit the main geometric features of the Montmarault massif. Profile 1 trends NW-SE across the whole pluton, it shows the sharp relationship between the pluton and the SHF. Profile 2 trends SW-NE, it highlights the late reworking of the granitic massif by the Stephanian extension and half-graben basin formation.

Profile 1 (Figure 3) runs perpendicularly to the SHF, and a vertical fault is modeled on the right extremity of this section. To the first order, this geometry is consistent with both gravity and magnetic data, as one can observe in map view (Figures $2 a$ and $2 b$ ). To the west of the SHF, the Montmarault pluton thickens toward the SHF. Its bottom deepens up to $2 \mathrm{~km}$ close to the fault. As shown by the low-gravity anomaly that underlines the Montmarault granitic massif along the SHF (Figure 2a), this geometry is also reproduced in the other four cross sections oriented in the same direction, suggesting rooting of the pluton along the SHF.

The central part of profile 1, which is marked by low gravity and magnetic anomalies, corresponds to the Stephanian Cosne d'Allier basin, around $500 \mathrm{~m}$ thick, as constrained by 
bore holes [Turland et al., 1989]. The basin thickens toward the Montmarault pluton, and the contact is the Murat fault. In Figure 1a, this contact is almost everywhere faulted, to the SW, south and SE of the basin. To the west, the basin gently thins out and is progressively replaced at the surface by porphyritic monzogranite and leucogranite belonging to the Montmarault massif. The accounted strong increase in both the magnetic and gravity anomalies cannot be fitted by granitic rocks only. In particular, the high-gravity anomaly is not in agreement with thickening of the low-density granitic pluton. Therefore the presence of a dense and high magnetic material underneath is required. Sub-outcropping dioritic intrusions are a good candidate, as between Cosne d'Allier and Villefranche, diorite is exposed just few kilometers apart. Along this profile, to the SE, two dioritic bodies in association with the thickest part of the Montmarault pluton are modeled. One of these bodies crops out as a large septum enclosed in the granodiorite, the second one is interpreted at depth.

In map view (Figure 1a), profile 2 crosscuts alternatively granites and Stephanian basins. In section view (Figure 3), this profile 2 shows the late reworking of the Montmarault massif by two faults that control the opening of the Commentry and Montvicq coal basins. The two basins are associated with two negative magnetic and gravity anomalies. The Stephanian coal basins are modeled integrating the geologic cross sections by Turland et al. [1989]. Both basins are half-grabens with a maximum sediment thickness of $500 \mathrm{~m}$, opened along NW-SE trending listric faults. The sedimentary rocks deposited in these basins directly overly the Montmarault granodiorite while they are tilted to the SE. Subjacent migmatite, diorite and gneiss are also affected by the tilting. To the south of Commentry, the gravity increase and magnetic decrease correspond to the emergence of the metamorphic basement to the surface. These three magnetic highs are satisfactorily explained by three dioritic bodies underlying the Montmarault pluton, since the thickness of the pluton is controlled by the relatively high gravity anomaly (Figure 3, profile 2). This situation is comparable to that in the NW of profile 1.

\section{Discussion}

Brittle post-Stephanian activity of the Sillon Houiller Fault is the only described motion of this fault [Grolier and Letourneur, 1968; Feybesse, 1981; Belin, 1983]. Several previous geophysical studies together with our own results, however, suggest that this present lithospheric-scaled fault might have played a ductile role to accommodate the late-orogenic extensional event of the FMC, even if in this study, no data provide the evidence of a lithospheric scale fault in the Variscan time.

Methodologically, the 3-D geologic and geophysical model allows to simultaneously integrate the data from different investigations such as petrophysical measurements, structural orientations of different geological lithologies (AMS and field), 2-D conjoint gravity and magnetic cross sections. The coherent integration of information from various sources allows us to proceed from an intuitive and qualitative geological understanding to a quantitative description of the geology. On the basis of these integrated results, an emplacement model of the Montmarault pluton in relation with the SHF is discussed.

The Montmarault magmatism is dated at $321 \pm 2 \mathrm{Ma}$ (see part 1). The magnetic fabric in the pluton is acquired during emplacement; it shows a predominant NW-SE magnetic lineation, perpendicular to the SHF and that complies with regional extensional tectonics (see part 1). 
The negative gravity anomaly along the SHF (Figure 2a) and NE-SW trending foliation of the pluton associated to a NW-SE orientated magnetic lineation, both steeply plunging toward the SHF (Figure 13 in part 1), support the interpretation that this syntectonic pluton is rooted in the SHF and spreads toward the northwest with a laccolite-like shape. Indeed, if the SHF existed at the time of pluton emplacement, i.e., in Namurian times, this fault, named the "Proto-Sillon Houiller Fault," would have acted as a feeder zone for the magma. However, in the field, no Namurian ductile offset has been documented along the SHF. Therefore the proposed emplacement model and the kinematics of the SHF remain hypothetical.

Two distinct and successive episodes of extensional tectonics have been documented in the FMC [e.g., Faure and Becq-Gireaudon, 1993; Faure, 1995]. The first episode occurred during early Late Carboniferous, at around 325-310 Ma. The Montmarault granitic massif was emplaced during this period at circa $320 \mathrm{Ma}$ (part 1). At that time, numerous syntectonic granitic plutons were emplaced throughout the FMC [e.g., Faure, 1995; Talbot et al., 2004, 2005; Be Mezème et al., 2006; Gébelin et al., 2004, 2006]. Magmatic fabrics in these plutons show a maximum NW-SE stretching direction, developed on both sides of the SHF (Figure 15 in part 1). In the Montmarault pluton, the NW-SE magnetic lineation that we describe in part 1 is in accordance with this regional pattern. The perpendicular lineation to the SHF excludes the possibility of strike-slip motion along the SHF during the Montmarault pluton emplacement.

Furthermore, we have observed along the NE margin of the Montmarault pluton (Figure $4 \mathrm{~d}$ in part 1), a top-to-the-NW shearing associated to a gentle dip to the NW and a vertical lineation, demonstrating an extensional regime for the pluton emplacement. Therefore the "proto-SHF" should have behaved as a normal fault during this NW-SE directed extensional phase, although no field evidences of ductile deformation along the SHF have been observed in the northern part of the SHF. At a regional scale, the NW-SE extension along the SHF, which took place during the Namurian belt-parallel syn-orogenic extensional event [Faure, 1995], is consistent with the NW-SE extension attested in several granitic massifs, as well as local strike-slip movements along transfer faults in the Limousin area [Gébelin et al., 2004, 2006].

During the second Late Carboniferous-Early Permian extensional episode, N-S to NE-SW stretching developed in the FMC [둘, 1995]. The opening of the intramountain coal basins throughout the FMC, either as half graben or pull-apart structures, complies with this tectonic pattern. At that time, the SHF behaved as a left lateral brittle wrench fault in accordance with this general pattern [Grolier and Letourneur, 1968; Feybesse, 1981; Blès et al., 1989]. The NE-SW extension is also well recorded by the syntectonic Stephanian basins in the Montmarault area. Our modeling shows the pluton extends underneath most of these basins, the opening of which was controlled by listric faults [Faure, 1995]. At present, the Montmarault pluton outcropping limits correspond to the brittle part of those listric faults that roughly trend perpendicular to the SHF (Figure 3 and Animation 1).

Concerning the deeper geological units, our modeling shows that the northern and western parts of the Montmarault pluton are underlain by significant amounts of relatively dense and highly magnetic materials, as already suspected [Boissonas and Debeglia, 1976]. In the Montmarault area, outcrops of the dioritic plutons are limited, but we assume that dioritic bodies are the likely source for the observed gravity and magnetic anomalies since this mafic lithology is the only significantly magnetic rock outcropping in the area (Figures $2 \mathrm{~d}$ and 3 
and Animation 1). Moreover, abundant calc-alkaline gabbro, diorite and tonalite plutons crop out in the Limousin area [e.g., Didier and Lameyre, 1971; Peiffer, 1986; Shaw et al., 1993; Cuney et al., 1993; Faure et al., 2005]. These plutons were emplaced during the Middle to Late Devonian (circa 380-370 Ma) and often exhibit a solid-state deformation developed at the pluton margins before the Namurian extensional tectonics. In the west of the study area, diorite and tonalite plutons crop out along the Marche fault (Figure 1b) [Bouvier, 1985]. The dioritic intrusions recognized in the Montmarault area belong to this group. Their calcalkaline geochemistry and their place in the geological framework of the Variscan Belt led some authors to propose that the deep part of magmatic arcs consists of diorites [Peiffer, 1986; Pin, 1990; Pin and Paquette, 1997; Faure et al., 2005]. Together with host rocks, the diorites were involved in the Late Devonian-Early Carboniferous ductile event that predates the Middle to Late Carboniferous magmatic event, which includes emplacement of the Montmarault pluton. The discussion of the early geodynamics of the FMC is beyond the scope of this paper [see Ledru et al., 1989; Faure et al., 2005]. Nevertheless, on the basis of the regional knowledge, the presence of dioritic intrusions at depth in the Montmarault area appears a reasonable assumption.

\section{Conclusions}

Gravity and magnetic data document the bulk geometry of the Montmarault massif. From east to west, the Montmarault granitic pluton is rooted in the SHF and intrudes the metamorphic series as a kilometer-thick laccolith. Together with AMS data, these 2-D results are interpolated into a 3-D geometrical model which integrated all currently available data and geological knowledge. A realistic geometry of Montmarault pluton is proposed, which highlights its geological history. Present V-shape geometry of Montmarault massif, structured by Stephanian half-graben coal basins was acquired during the well-documented Late Carboniferous NE-SW extensional phase. Along the SHF, this tectonic phase overprints most evidences of the Namurian ductile tectonics that prevailed during the emplacement of Montmarault massif. Our AMS and joint gravity-magnetic modeling results show that the syntectonic granitic massif roots along the SHF. And, as the pluton was emplaced in a general NW-SE extensional tectonic setting, combined with AMS results in the pluton, we therefore conclude that if the "Proto Sillon Houiller Fault" existed in Namurian times, it acted as a normal fault, at least in its northern part. In order to assess the SHF tectonic behavior at the scale of the FMC during the late orogenic stages, additional field and laboratory studies in the southern part of the SHF are needed.

\section{Acknowledgments}

[44] We are grateful to M. Diament for providing us a SCINTREX CG3-M microgravimeter. We also thank the 3-D Geomodeller team: Gabriel Courrioux, Antonio Guillen, Philippe Calcagno, and Intrepid Geophysics team. Reviews from Pierre Keating, Olivier Vanderhaege, and an anonymous reviewer allowed us to significantly improve the manuscript. Geophysical maps and 2-D joint gravity and magnetic forward modeling were achieved using Geosoft-GM-SYS package. 


\section{References}

Améglio, L., J. L. Vigneresse, and J. L. Bouchez (1997), Granite pluton geometry and emplacement mode inferred from combined fabric and gravity data, in Granite: From Segregation of Melt to Emplacement Fabrics, edited by J.-L. Bouchez, D. H. W. Hutton, and W. E. Stephens, pp. 199-214, Kluwer Acad., Dordrecht, Netherlands.

Aranguren, A., J. M. Tubia, J. L. Bouchez, and J. L. Vigneresse (1996), The Guiritz granite, Variscan belt of northern Spain: Extension-controlled emplacement of magma during tectonic escape, Earth Planet. Sci. Lett., 139, 165-176.

Aug, C. (2004), Modélisation géologique 3D et caractérisation des incertitudes par la méthode du champ de potentiel, Ph.D. thesis, École des Mines de Paris, Paris.

Babuška, V., J. Plomerová, L. Vecsey, M. Granet, and U. Achauer (2002), Seismic anisotropy of the French Massif Central and predisposition of Cenozoic rifting and volcanism by Variscan suture hidden in the mantle lithosphere, Tectonics, 21(4), 1029, doi:10.1029/2001TC901035.

Barbarin, B., J. M. Belin, A. Fernandez, J. Grolier, A. Lacour, and M. Turland (1985), Observations de pétrologie structurales sur le granite de Montmarault (Allier, Puy-de-Dôme), Geol. Fr., 4, 381-388.

Belin, J.-M. (1983), Le massif de Saint-Gervais d'Auvergne (Massif Central français). Evolution d'un ensemble granitique composite, Ph.D. thesis, 196 pp., Clermont-Ferrand II Univ., Clermont-Ferrand, France.

Be Mezème, E., M. Faure, Y. Chen, A. Cocherie, and J.-Y. Talbot (2006), Structural, AMS and geochronological study of a laccolith emplaced during Late Variscan orogenic extension: The Rocles pluton (SE French Massif Central), Int. J. Earth Sci., 96, 215-228, doi:10.1007/s00531-006-0098-2.

Benn, K., R. J. Horne, D. J. Kontak, G. Pignotta, and N. G. Evans (1997), Syn-Acadian emplacement model for the South Mountain Batholith, Meguma Terrane, Nova Scotia: Magnetic fabric and structural analyses, Geol. Soc. Am. Bull., 109, 1279-1293.

Benn, K., N. M. Ham, G. S. Pignotta, and W. Bleeker (1998), Emplacement and deformation of granites during transpression: Magnetic fabrics of the Archean Sparrow pluton, Slave Province, Canada, J. Struct. Geol., 20, 1247-1259.

Benn, K., W. R. Roest, P. Rochette, N. G. Evans, and G. S. Pignotta (1999), Geophysical and structural signature of syntectonic batholith construction: The South Mountain Batholith, Meguma Terrane, Nova Scotia, Geophys. J. Int., 136, 144-158.

Berthier, F., J.-L. Duthou, and M. Roques (1979), Datation géochronologique Rb/Sr sur les roches totales du granite de Guéret (Massif Central). Age fini-dévonien de la mise en place de l'un de ses faciès, Bull. Bur. Rech. Geol. Min. Fr., Ser. 2, 1(2), 59-72. 
Blès, J. L., D. Bonijoly, C. Castaing, and Y. Gros (1989), Successive post-Variscan stress fields in the French Massif Central and its borders (western European plate): Comparison with geodynamic data, Tectonophysics, 169, 79-111.

Boissonas, J., and N. Debeglia (1976), Etude géophysique du granite magnétique de Montmarault (Allier) et corrélation avec la pétrographie, Rapp. BRGM 76 SGN 401 GPH, Bur. de Rech. Geol. et Min., Orléans, France.

Bonijoly, D., and C. Castaing (1984), Fracturation et genèse des bassins stéphaniens du Massif central français en régime compressif, Ann. Soc. Geol. Nord, 103, 187-199.

Bouchez, J. L., and G. Gleizes (1995), Two-stage deformation of the Mont-Louis-Andorra granite pluton (Variscan Pyrenees) inferred from magnetic susceptibility anisotropy, J. Geol. Soc. London, 152, 669-679.

Bouvier, P. (1985), Les gabbro-diorites du domaine de Boussac. Pétrographie, minéralogie, géochimie. Relations avec le magmatisme acide du domaine de la Marche-Guéret, Ph.D. thesis, 262 pp., Orsay Univ., Paris XI, Orsay, France.

Brun, J. P., and J. P. Burg (1982), Combined thrusting and wrenching in the Ibero-Armorican arc: A corner effect during continental collision, Earth Planet. Sci. Lett., 6, 319-332.

Brun, J. P., D. Gapais, J. P. Cogné, P. Ledru, and J. L. Vigneresse (1990), The Flamanville granite (NW France): An unequivocal example of an expanding pluton, Geol. J., 25, 271-286.

Burg, J. P., J. P. Brun, and J. Van Den Driessche (1990), Le Sillon Houiller du Massif Central français: Faille de transfert pendant l'amincissement crustal de la chaîne varisque?, C. R. Acad. Sci., Ser. II, 311(1), 147-152.

Burg, J. P., J. Van Den Driessche, and J. P. Brun (1994), Syn- to post thickening in the Variscan Belt of the Western Europe: Modes and structural consequences, Geol. Fr., 3, 33-51.

Cartannaz, C., P. Rolin, A. Cocherie, D. Marquer, O. Legendre, C. M. Fanning, and P. Rossi (2006), Characterization of wrench tectonics from dating of syn- to post-magmatism in the north-western French Massif Central, Int. J. Earth Sci., 96, 271-287, doi:10.1007/s00531006-0101-y.

Castro, A. (1986), Structural pattern and ascent model in the Central Extremadura Batholith, Hercynian Belt, Spain, J. Struct. Geol., 8, 633-645, doi:10.1016/0191-8141 (86)90069-6.

Crawford, M. L., K. A. Klepeis, G. Gehrels, and C. Isachsen (1999), Batholith emplacement at midcrustal levels and its exhumation within an obliquely convergent margin, Tectonophysics, 312, 57-78, doi:10.1016/S0040-1951 (99)00170-5.

Cruden, A. R., and P. Launeau (1994), Structure, magnetic fabric and emplacement of the Archean Lebel Stock, SW Abitibi Greenstone Belt, J. Struct. Geol., 16, 677-691.

Cuney, M., J. M. Stussi, M. Brouand, D. Dautel, A. Michard, Y. Gros, D. Poncet, P. Bouton, M. Colchen, and J. P. Vervialle (1993), Géochimie et géochronologie U/Pb des diorites 
quartziques du Tallud et de Moncoutant: Nouveaux arguments pour une extension de la "Ligne Tonalitique Limousine" en Vendée, C. R. Acad. Sci., Ser. II, 316(10), 1383-1390.

Debeglia, N. (1973), Levé areomagnétique Massif Central 1972: Compilation, Rapp. BRGM 73 MET/GPH 029, Bur. de Rech. Geol. et Min., Orléans, France.

Debeglia, N., and A. Gérard (1975), Eléments interprétatifs de bases obtenus à l'issue du levé aeromagnétique "Massif central 1972", BRGM report, 36 pp., Bur. de Rech. Geol. et Min., Orléans, France.

Didier, J., and J. Lameyre (1971), Les roches granitiques du Massif Central, in Géologie, Géochronologie et Structure Profonde du Massif Central Français, Symposium Jung Clermont-Ferrand, pp. 133-155, Plein Air Serv., Clermont-Ferrand, France.

Edel, J. B., and A. Gachon (1973), Massif central: Levé aéromagnétique 1972, Rapp. BRGM 73 MET/GPH 030, Bur. de Rech. Geol. et Min., Orléans, France.

Faure, M. (1995), Late Carboniferous extension in the Variscan French Massif central, Tectonics, 14, 132-153.

Faure, M., and J. F. Becq-Gireaudon (1993), Sur la succession des épisodes extensifs au cours du désepaississement carbonifère du Massif Central Français, C. R. Acad. Sci., Ser. II, 316, 967-973.

Faure, M., J. Grolier, and J. Pons (1993), Extensional ductile tectonics of the Sioule metamorphic series (Variscan French Massif Central), Geol. Rundsch., 82, 461-474.

Faure, M., E. Be Mézème, M. Duguet, C. Cartier, and J.-Y. Talbot (2005), Paleozoic tectonic evolution of Medio-Europa from the example of the French Massif central and Massif Armoricain, J. Virtual Explorer, 19(5), 26 pp.

Feybesse, J. L. (1981), Tectonique et microtectonique de la région de Laroquebrou (Cantal, Massif central français). Rôle de la déformation ductile et évolution du Sillon Houiller, Ph.D. thesis, 250 pp., Clermont Ferrand Univ., Clermont Ferrand, France.

Gébelin, A., G. Martelet, M. Brunel, M. Faure, and P. Rossi (2004), Late Hercynian leucogranites modeling as deduced from new gravity data: The example of the Millevaches massif, Massif Central, France, Bull. Soc. Geol. Fr., 175(3), 239-248.

Gébelin, A., G. Martelet, Y. Chen, M. Brunel, and M. Faure (2006), Structure of late Variscan Millevaches leucogranite massif in the French Massif Central: AMS and gravity modelling results, J. Struct. Geol., 28, 148-169.

Gleizes, G., D. Leblanc, and J. L. Bouchez (1997), Variscan granites of the Pyrenees revisited: Their role as syntectonic markers of the orogen, Terra Nova, 9, 38-41.

Granet, M., G. Stoll, J. Dorel, U. Achauer, G. Poupinet, and K. Fuchs (1995a), Massif Central (France): New constraints on the geodynamical evolution from teleseismic tomography, Geophys. J. Int., 121, 33-48. 
Granet, M., M. Wilson, and U. Achauer (1995b), Imaging a mantle plume beneath the French Massif Central, Earth Planet. Sci. Lett., 136, 281-296.

Granet, M., S. Judenherc, and A. Souriau (2000), Des images du système lithosphère asthénosphère sous la France et leurs implications géodynamiques: L'apport de la tomographie télésismique et de l'anisotropie sismique, Bull. Soc. Geol. Fr., 171(2), 149-167.

Grolier, J., and J. Letourneur (1968), L'évolution tectonique du grand Sillon Houiller du Massif Central français, paper presented at XXIII International Geological Congress, Int. Union of Geod. and Geophys., Florence, Italy.

Guillen, A., V. Delos, and P. Ledru (2000), A new method to determine lithology and geometry in depth: 3D litho-inversion of potential fields, extended abstract presented at 25th General Assembly of the European Geophysical Society, Katlenburg-Lindau, Germany.

Guillen, A., G. Courrioux, P. Calcagno, R. Lane, T. Lees, and P. McInerney (2004), Constrained gravity inversion applied to Broken Hill, extended abstract in presented at 17th Geophysical Conference and Exhibition of the Australian Society of Exploration Geophysicists, Sydney, Australia.

Guillen, A., A. Joly, P. Calcagno, G. Courrioux, D. Fitzgerald, P. McInerney, and R. Seikel (2006), Coupling 3D modeling and forward-inverse modeling of potential field data (gravity and magnetic data and tensor components), extended abstract presented at International Association for Mathematical Geology 2006, Liege, Belgium.

Hutton, D. H. W. (1982), A tectonic model for the emplacement of the Main Donegal granite, NW Ireland, J. Geol. Soc. London, 139, 615-631.

Hutton, D. H. W. (1988), Granite emplacement mechanisms and tectonic controls: Inferences from deformation studies, Trans. R. Soc. Edinburgh Earth Sci., 79, 452-455.

Joly, A., Y. Chen, M. Faure, and G. Martelet (2007), A multidisciplinary study of a syntectonic pluton close to a major lithospheric-scale fault-Relationships between the Montmarault granitic massif and the Sillon Houiller Fault in the Variscan French Massif Central: 1. Geochronology, mineral fabrics, and tectonic implications, J. Geophys. Res., 112, B10104, doi:10.1029/2006JB004745.

Lajaunie, C., G. Courrioux, and L. Manuel (1997), Foliation fields and 3D cartography in geology: Principles of a method based on potential, interpolation, Math. Geol., 29, 571-584

Lardeaux, J.-M., P. Ledru, I. Daniel, and S. Duchene (2001), The Variscan French Massif Central: A new addition to the ultra-high pressure metamorphic club: Exhumation processes and geodynamic consequences, Tectonophysics, 332, 143-167.

Leblanc, D., G. Gleizes, P. Lespinasse, P. Olivier, and J. L. Bouchez (1994), The Maladeta granite polydiapir, Spanish Pyrenees: A detailed magneto-structural study, J. Struct. Geol., 16, 223-235. 
Leblanc, D., G. Gleizes, L. Roux, and J. L. Bouchez (1996), Variscan dextral transpression in the French Pyrenees: New data from the Pic des Trois-Seigneurs granodiorite and its country rocks, Tectonophysics, 261, 331-345.

Ledru, P., J. M. Lardeaux, D. Santallier, A. Autran, J. M. Quenardel, J. P. Floc'h, G. Lerouge, N. Maillet, J. Marchand, and A. Ploquin (1989), Où sont les nappes dans le Massif Central français?, Bull. Soc. Geol. Fr., 8, 605-618.

Lucazeau, F., G. Vasseur, and R. Bayer (1984), Interpretation of heat flow data in the French Massif Central, Tectonophysics, 103(1-4), 99-119.

Martelet, G., N. Debeglia, and C. Truffert (2002), Homogénéisation et validation des corrections de terrain gravimétriques jusqu'à la distance de $167 \mathrm{~km}$ sur l'ensemble de la France, C. R. Geosci., 334, 449-454.

Martelet, G., P. Calcagno, C. Gumiaux, C. Truffert, A. Bitri, D. Gapais, and J. P. Brun (2004), Integrated 3D geophysical and geological modeling of the Hercynian Suture Zone in the Champtoceaux area (south Brittany, France), Tectonophysics, 382(1-2), 117-128.

Matte, P. (1986), La chaîne varisque parmi les chaicirc;nes paléozoïques péri atlantiques, modèle d'évolution et position des grands blocs continentaux au Permo-Carbonifère, Bull. Soc. Geol. Fr., 8, 9-24.

McCaffrey, K. J. W. (1992), Igneous emplacement in a transpressive shear zone: Ox Mountains igneous complex, J. Geol. Soc. London, 149, 221-235.

McNulty, B. A., O. T. Tobisch, A. R. Cruden, and S. Gilder (2000), Multistage emplacement of the Mount Givens pluton, central Sierra Nevada Batholith, California, Geol. Soc. Am. Bull., 112, 119-135, doi:10.1130/0016-7606.

Ménard, G., and P. Molnard (1988), Collapse of a Hercynian Tibetan Plateau into a late Paleozoic European Basin and Range province, Nature, 334, 235-237.

Menichetti, V., and A. Guillen (1983), Simultaneous interactive magnetic and gravity inversion, Geophys. Prospect., 31, 929-944.

Molnar, P. (1988), Continental tectonics in the aftermath of platetectonics, Nature, 335, 131137.

Neves, S., and A. Vauchez (1995), Magmas emplacement and shear zone nucleation and development in northeast Brazil (Fazenda Nova and Pernambuco shear zones; state of Pernambuco), J. S. Am. Earth Sci., 8, 289-298.

Peiffer, M. T. (1986), La signification de la ligne tonalitique du Limousin. Son implication dans la structuration varisque du Massif Central français, C. R. Acad. Sci., Ser. II, 303(4), $305-310$.

Pe-Piper, G., I. Koukouvelas, and D. J. W. Piper (1998), Synkinematic granite emplacement in a shear zone: The Pleasant Hills pluton, Canadian Appalachians, Geol. Soc. Am. Bull., 110, $523-536$. 
Perrier, G., and J. C. Ruegg (1973), Structure profonde du Massif Central français, Ann. Geophys., 29, 435-502.

Pin, C. (1990), Variscan oceans: Ages, origins and geodynamic implications inferred from geochemical and radiometric data, Tectonophysics, 177, 215-227.

Pin, C., and J. L. Paquette (1997), A mantle-derived bimodal suite in the Hercynian Belt: Nd isotope and trace element evidence for a subduction-related rift origin of the late Devonian Brévenne metavolcanics, Massif Central (France), Contrib. Mineral. Petrol., 129, 222-238.

Santallier, D., J. M. Lardeaux, J. Marchand, and C. Marignac (1994), Metamorphism, in PreMesozoic Geology in France and Related Areas, edited by J. D. Keppies, pp. 325-340, Springer, New York.

Schellart, W. P., and G. S. Lister (2005), The role of the East Asian active margin in widespread extensional and strike-slip deformation in East Asia, J. Geol. Soc. London, 162, 959-972.

Shaw, A., H. Downes, and M. F. Thirlwall (1993), The quartz-diorites of Limousin: Elemental and isotopic evidence for Devono-Carboniferous subduction in the Hercynian belt of the French Massif Central, Chem. Geol., 107, 1-18.

Sobolev, S. V., H. Zeyen, M. Granet, U. Achauer, C. Bauer, F. Werling, R. Altherr, and K. Fuchs (1997), Upper mantle temperatures and lithosphere-asthenosphere system beneath the French Massif Central constrained by seismic, gravity, petrologic and thermal observations, Tectonophysics, 275(1-3), 143-164.

Sossa-Simawango, M. (1980), Contribution à la pétrologie, la géochimie, la géologie structurale du massif granitique de Montmarault (Massif central français), Ph.D. thesis, Orléans Univ., Orléans, France.

Talbot, J.-Y., G. Martelet, G. Courrioux, Y. Chen, and M. Faure (2004), Emplacement in an extensional setting of the Mont Lozère-Borne granitic complex (SE France) inferred from comprehensive AMS, structural and gravity studies, J. Struct. Geol., 26(1), 11-28.

Talbot, J.-Y., M. Faure, Y. Chen, and G. Martelet (2005), Pull-apart emplacement of the Margeride granitic complex (French Massif Central). Implications for the late evolution of the Variscan orogen, J. Struct. Geol., 27(9), 1610-1629.

Tapponier, P., and P. Molnar (1979), Active faulting and Cenozoic tectonics of the Tian Shan, Mongolia, and Baikal regions, J. Geophys. Res., 84, 3425-3459.

Teyssier, C., and B. Tikoff (1998), Strike-slip partitioned transpression of the San Andreas fault system: A lithospheric-scale approach, in Continental Transpressional and Transtensional Tectonics, edited by R. E. Holdsworth, R. A. Strachan, and J. F. Dewey, Spec. Publ. Geol. Soc., 135, 143-158, doi:10.1144/GSL.SP.1998.135.01.10.

Tikoff, B., and M. de Saint Blanquat (1997), Transpressional shearing and strike-slip partitioning in the Late Cretaceous Sierra Nevada magmatic arc, California, Tectonics, 16(3), $442-459$. 
Tikoff, B., and C. Teyssier (1992), Crustal-scale, en echelon "P-shear" tensional bridges: A possible solution to the batholithic room problem, Geology, 20, 927-930, doi:10.1130/00917613(1992)020<0927:CSEEPS>2.3.CO;2.

Tobisch, O. T., and A. R. Cruden (1995), Fracture-controlled magma conduits in an obliquely convergent continental magmatic arc, Geology, 23, 941-944, doi:10.1130/00917613(1995)023<0941:FCMCIA>2.3.CO;2.

Turland, M., et al. (1989), Notice explicative, carte géologie France, scale 1:50,000, feuille Bourbon l'Archambault, Montluçon, Montmarault, 82 pp., Bur. de Rech. Geol. et Min., Orléans, France.

Van den Driessche, J., and J. P. Brun (1989), Un modèle de l'extension paléozoïque supérieur dans le sud du Massif central, C. R. Acad. Sci., Ser. II, 309, 1607-1613.

Vanderhaege, O., and C. Teyssier (2001), Partial melting and flow of orogen, Tectonophysics, $342,451-472$.

Vigneresse, J. L. (1990), Use and misuse of geophysical data to determine the shape at depth of granitic intrusions, Geol. J., 25, 249-260.

Vigneresse, J. L., and J. L. Bouchez (1997), Successive granitic magma batches during pluton emplacement: The case of Cabeza de Araya (Spain), J. Petrol., 38, 1767-1776.

Vigneresse, J.-L., and J.-P. Brun (1983), Les leucogranites armoricains marqueurs de la déformation régionale: Apport de la gravimétrie, Bull. Soc. Geol. Fr., 25(3), 357-366.

Weinberg, R. F., P. F. Hodkiewicz, and D. I. Groves (2004), What controls gold distribution in Archean terranes?, Geology, 32, 545-548, doi:10.1130/G20475.1.

Zeyen, H., O. Novak, M. Landes, C. Prodehl, L. Driad, and A. Hirn (1997), Refractionseismic investigations of the northern Massif Central (France), Tectonophysics, 275(1-3), 99117. 


\section{Figures}

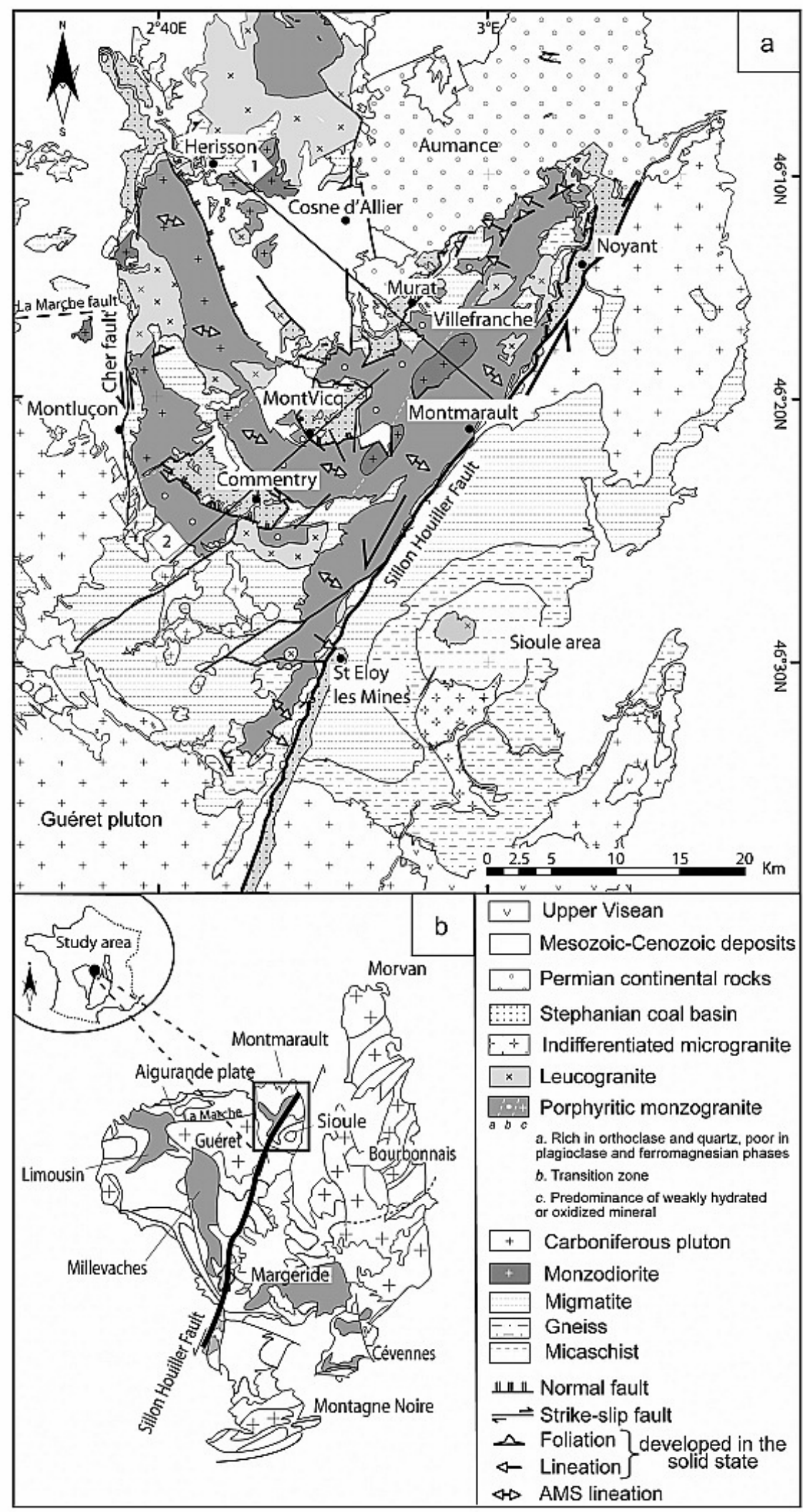

Figure 1. Structural map of (a) the Montmarault massif in (b) the French Massif Central. Black thin lines indicate the locations of the two gravity-magnetic models presented in this paper. Enhanced TIF 

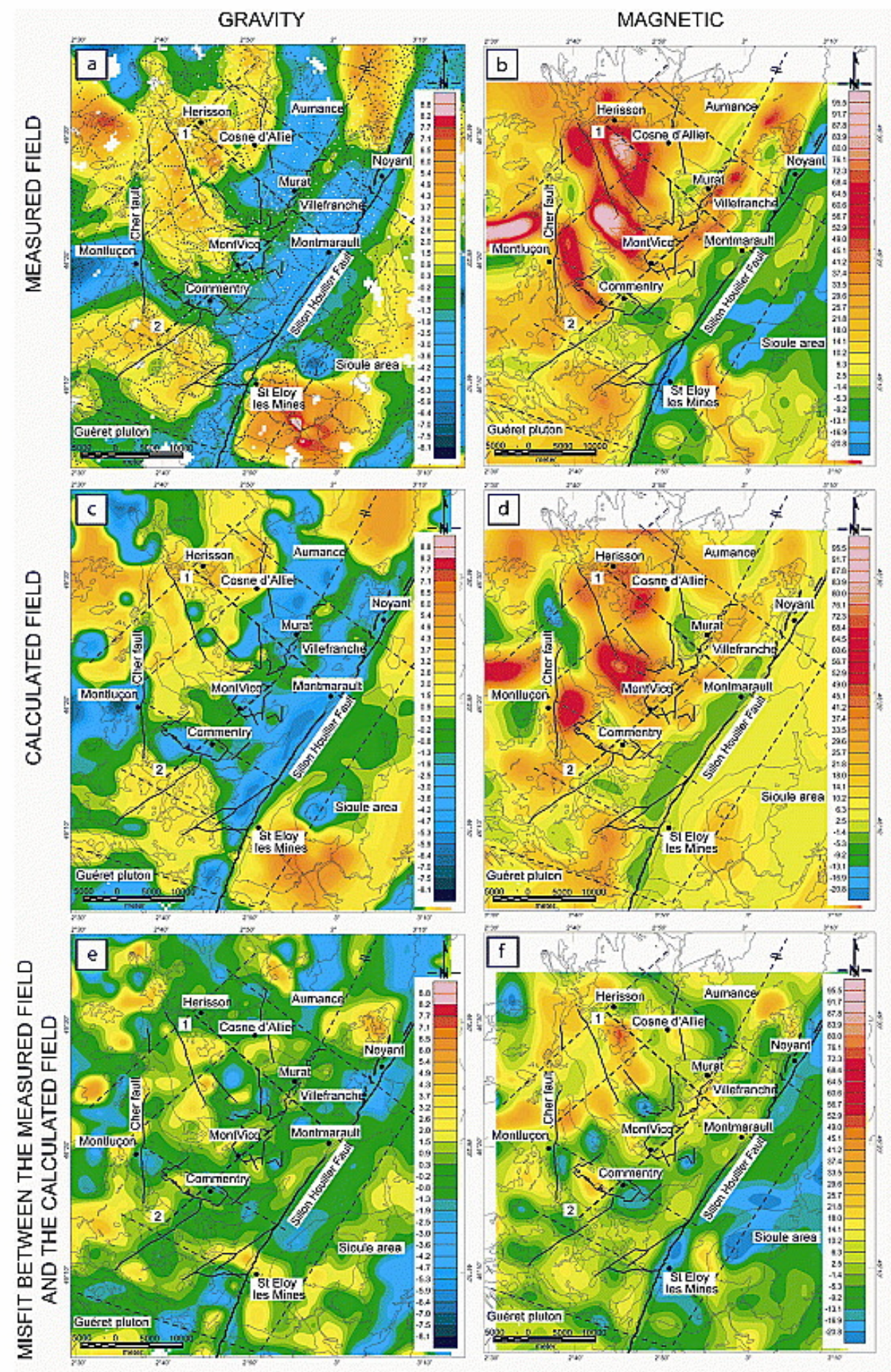

Figure 2. Measured, calculated, and misfit maps of the gravity and magnetic field. Major geological limits (thin black lines), faults (thick black lines), and locations of the gravity-magnetic profiles (dashed black lines) are drawn. (a) Residual Bouguer anomaly map of the Montmarault pluton with locations of previous (black dots) and new (white dots) gravity stations. (b) Reduced to pole magnetic map of the Montmarault pluton. (c) Computed 3-D gravity effect of the 3-D model, using densities reported in Figure 3. (d) Computed 3-D magnetic effect of the 3-D model, using susceptibilities reported in Figure 3. (e) Misfit gravity map showing the discrepancies between the Bouguer anomaly map and the calculated one. (f) Misfit magnetic map showing the discrepancies between the reduced to the pole anomaly map and the calculated one. Enhanced TIF 


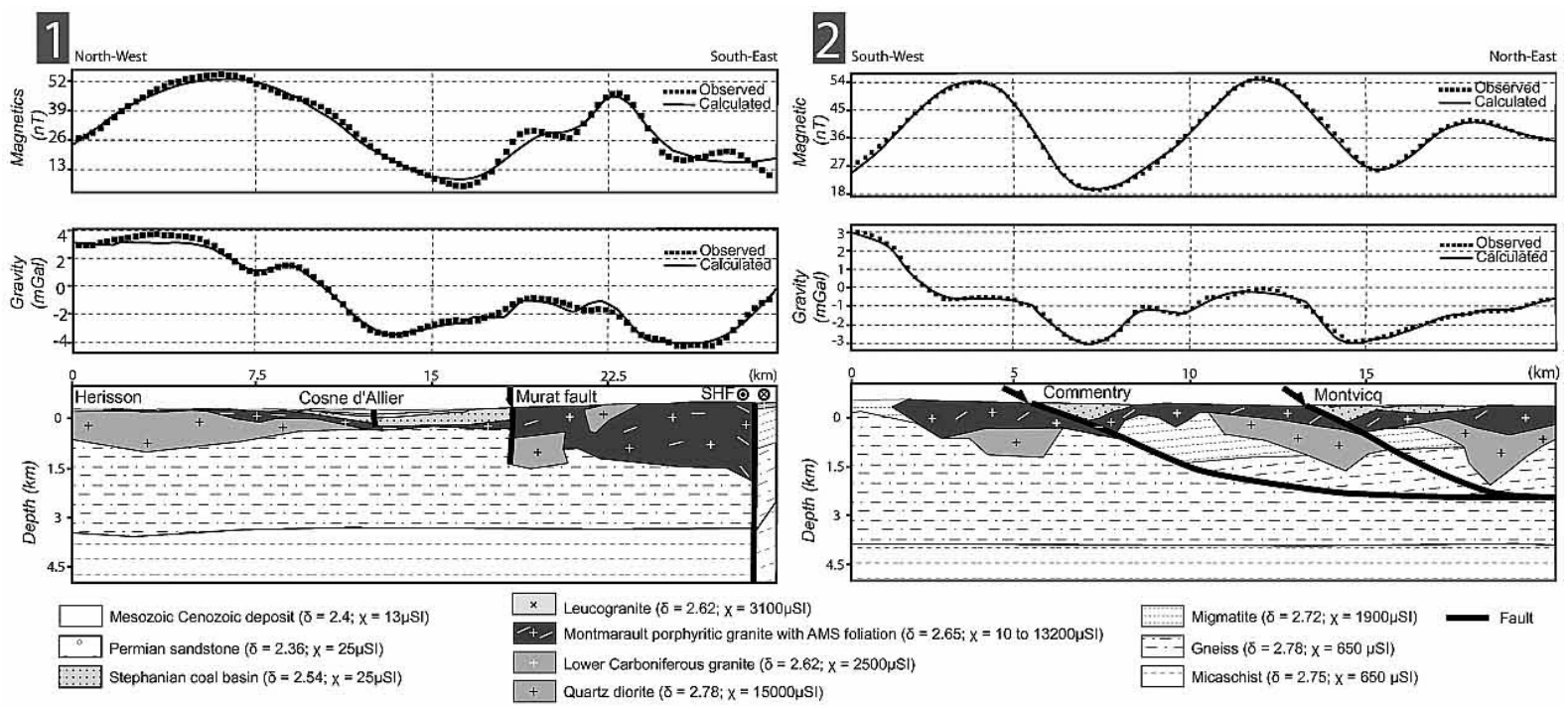

Figure 3. Joint modeling of Bouguer and magnetic anomalies along profiles 1 and 2 (see location on Figure 1a). AMS foliations are represented by white lines. In the top panel the model magnetic effect (thin black curve) has been fitted to magnetic anomaly data (black dots) using surface geology (lithologies and structural data in the bottom panel) and their petrophysical properties (density and magnetic susceptibility). In the middle panel, the model gravity effect has been fitted to Bouguer anomaly data using surface geology in the same way. Enhanced TIF

\section{Table}

Table 1. Density and Magnetic Susceptibility Measurements of Geological Formations Outcropping Along the SHF

\begin{tabular}{|l|l|l|l|l|c|}
\hline \multicolumn{1}{|c|}{ Formation } & \multicolumn{1}{|c|}{ Rock type } & n & \multicolumn{1}{|c|}{$\begin{array}{c}\text { Density, } \\
\text { g.cm }\end{array}$} & n & $\begin{array}{c}\text { Susceptibility, } \\
\text { MSI }\end{array}$ \\
\hline Mesozoic cover & $\begin{array}{l}\text { mainly calcareous } \\
\text { sediments }\end{array}$ & 3 & $2.35-2.45$ & 3 & $5-19$ \\
\hline Permian basin & sandstone & 4 & $2.31-2.41$ & 5 & $12-38$ \\
\hline Stephanian coal basin & sandstone & 3 & $2.50-2.58$ & 5 & $13-39$ \\
\hline Montmarault leucogranite & leucogranite & 5 & $2.59-2.65$ & 6 & $2475-3725$ \\
\hline $\begin{array}{l}\text { Namurian Montmarault } \\
\text { granite }\end{array}$ & porphyroid granite & 5 & $2.62-2.68$ & 20 & $10-13200$ \\
\hline $\begin{array}{l}\text { Late Carboniferous Gueret } \\
\text { granite }\end{array}$ & $\begin{array}{l}\text { calc-alkaline porphyroid } \\
\text { granite }\end{array}$ & 2 & $2.59-2.65$ & 5 & $2050-2950$ \\
\hline Devonian diorite & diorite & 2 & $2.74-2.82$ & 5 & $11850-18150$ \\
\hline Metamorphic basement & migmatite & 5 & $2.69-2.75$ & 7 & $1520-2280$ \\
\hline Metamorphic basement & gneiss & 4 & $2.73-2.83$ & 5 & $585-715$ \\
\hline Metamorphic basement & micaschist & 2 & $2.71-2.79$ & 2 & $586-715$ \\
\hline
\end{tabular}

